\title{
Prevalence of Hepatitis B Surface Antigen among Undergraduate Students of Gombe State University, Gombe
}

\author{
Wasa A. A ${ }^{1}$ and Maigana A. ${ }^{2}$ \\ Department of Biological Sciences, Faculty of Science, Gombe State University, P. M. B 127 Gombe
}

\begin{abstract}
Incidence of Hepatitis B virus among healthy asymptomatic students in Gombe State University was determined, this was in an effort of providing baseline data on the diseases burden, and the possible risk factors associated with the infection in the study population. A total of 100 serum samples were collected from volunteers and screened using rapid immune chromatographic test kits for Hepatitis B surface antigen (HBsAg). The study revealed that $14 \%$ were HBsAg positive. The highest incidence rate of $18.2 \%$ (12) was recorded among the age group of 16-25 years, and males recorded the highest incidence rate of 20\% (12), indicating that gender but not age might have greater influence on the infection $(P=0.05)$.
\end{abstract}

Key words: Hepatitis B surface antigen (HBs Ag), Incidence, Seropositivity, Seroprevalence, Age group, Gender

Submitted date 12 June 2013

Accepted Date: 17 June 2013

\section{Introduction}

Hepatitis is an inflammation of the liver as a result of a variety of causes, which are both infectious and non-infectious. The infectious agents that cause hepatitis include virus, bacteria and parasites, while the noninfectious substances include certain drugs and toxic agents (Rice and Dobuission, 1996). Hepatitis B virus (HBV) is the most prevalent, most predominant cause of viral hepatitis and the leading cause of hepatocellular carcinoma (Hollinger et al., 2001). It can be found in serum, vaginal secretions, breast milk and of low concentration in the saliva of infected persons (Lindsley et al., 1990). Approximately 240,000 new cases occur each year and as many as 1-6\% of infected adults become carriers of the disease (Nester et al., 2007). The World Health Organization (WHO) estimated that 350 million people in the world are carriers in endemic areas such as Sub-Saharan Africa, South East Asia and South America, most of who were reported to have acquired it prenatally (Hadler et al., 1991).

A study carried out on the prevalence of anti-HBs antibody among 427 six year old children 223 (52.2\%) females and $204(47.8 \%)$ males in Ahvaz, Iran. 5 year after vaccination, revealed that non-responders have peak anti-HBs levels of $<10 \mathrm{mlv} / \mathrm{mi}$, low responders have peak anti-HBs levels of $10-100 \mathrm{mlv} / \mathrm{mi}$ and good responders have peaked anti-HBs levels of $>100 \mathrm{mlv} / \mathrm{mi}$.

There was no any significant statistical difference between females and males in low responders groups (Ahmad, 2011).

In Nigeria reports on serum carrier rate of the surface antigen of Hepatitis B virus (HBs Ag) showed that the infection is prevalent and endemic. Surveys conducted among blood donors in various locations revealed the following prevalence rate; $13 \%$ in Ibadan (Ayoola and Adejala, 1998), 13.3\% in Lagos (Nasidi et al., 1991), 22\% in Maiduguri (Harry et al., 1994) and a prevalence rate of $8.3 \%$ was also reported for a study conducted in Zaria (Ibrahim, 2005).

Global widespread Hepatitis B seropositivity among healthy asymptomatic persons and lack of proper information on prevalence rates among undergraduates who are mostly at risk due to their nature and life style necessitated this research.

This study was carried out among healthy asymptomatic undergraduate students of Gombe State University to determine the incidence of Hepatitis B surface antigen ( $\mathrm{HBs} \mathrm{Ag}$ ) by age groups and gender and make appropriate recommendations based on the findings.

\subsection{Study population and site}

\section{Materials and Methods}

The study population comprises of about one hundred volunteer undergraduate students of all levels from all faculties in Gombe State University within the age group of 15-35 years.

\subsection{Sample collection}

The consent of volunteers for this research was sought and approval from the University authorities was received before sample collection. A trained nurse in the University clinic aseptically collected two (2) ml 
of blood samples from each of the 100 volunteers into sterile EDTA bottles and transported immediately from the clinic to the laboratory for analysis (Cheesbrough, 2006)

\subsection{Sample processing and screening for HBsAg}

Blood samples were screened for presence of HBsAg using Global one step HBs Ag test strips (serum/plasma) package inserts, by immersing the test strip vertically in to the serum for 10 seconds and placing on a non adsorbent surface for a period of 10 minutes after which the result is interpreted according to manufacturer's instructions as follows: presence of colored line indicates a positive result, while absence of a colored line indicates a negative result.

\section{Results}

From the analysis conducted, Table. 1 shows $14(14 \%)$ incidence, $4(4 \%)$ invalid result and $82(82 \%)$ negative result for HBsAg among the students investigated. The incidence according to age is shown in Table .2. The highest incidence of $18.2 \%$ was observed among the age group 16-25years, while the lowest $5.9 \%$ was observed in the 26-35 years age group. The age group has no influence on the infection i.e. there is no association between HBsAg and age after chi square $\left(\mathrm{X}^{2}\right)$ test (Table.3).

The incidence by gender showed incidence rate of $20 \%$ (12 positive cases) and 5\% ( 2 positive cases) for male and female students respectively as shown in Table. 4. Chi square $\left(\mathrm{X}^{2}\right)$ test $(\mathrm{P}=0.05)$ indicates that there is a significant association between HBsAg infection and gender; with men more predisposed than females

TABLE 1: Total incidence of Hepatitis B surface antigen (HBsAg)

\begin{tabular}{|c|c|c|c|}
\hline \multicolumn{2}{|c|}{$\mathrm{HBsAg}$} & \multicolumn{2}{|r|}{ Total } \\
\hline+ & - & Invalid & \\
\hline $14(14 \%)$ & $82(82 \%)$ & $4(4 \%)$ & $100(100 \%)$ \\
\hline
\end{tabular}

Key: $+=$ positive,$\quad-=$ negative, $\%=$ percentage

TABLE 2: Incidence of Hepatitis b surface antigen (HBsAg) by age

\begin{tabular}{lcccc}
\hline Age $(\mathrm{yrs})$ & & \multicolumn{2}{c}{ HBsAg infection $(\%)$} & Total \\
\cline { 2 - 5 } & + & - & Invalid & \\
\hline $16-25$ & $12(18.2 \%)$ & $52(78.8 \%)$ & $2(3.0 \%)$ & $66(100 \%)$ \\
$26-35$ & $2(5.9 \%)$ & $30(88.2 \%)$ & $2(5.9 \%)$ & $34(100 \%)$ \\
\hline Total & $14(14.0 \%)$ & $82(82.0 \%)$ & $4(4.0 \%)$ & $100(100 \%)$ \\
\hline
\end{tabular}

TABLE 3: Chi Square $\left(X^{2}\right)$ Test (association between age and HBsAg infection among Undergraduate students in Gombe State University)

\begin{tabular}{lccc}
\hline Age $(\mathrm{yrs})$ & Observed frequency $(\mathrm{O})$ & Expected frequency $(\mathrm{E})$ & $\underline{(\mathrm{O}-\mathrm{E}}^{2}$ \\
& & & $\mathrm{E}$ \\
\hline $16-25$ & 12 & 9.33 & 0.76 \\
$26-35$ & 2 & 4.66 & 1.52 \\
Total & 14 & 13.99 & 2.28 \\
\hline
\end{tabular}

TABLE 4: Incidence of Hepatitis b surface antigen (HBsAg) by gender

\begin{tabular}{lcccc}
\hline Gender & & \multicolumn{2}{c}{ HBsAg infection (\%) } & Total \\
& + & - & Invalid & \\
\hline Male & $12(20.0 \%)$ & $46(76.7 \%)$ & $2(3.3 \%)$ & $66(100 \%)$ \\
Female & $2(5.0 \%)$ & $36(90.0 \%)$ & $2(5.0 \%)$ & $40(100 \%)$ \\
\hline Total & $14(14.0 \%)$ & $82(82.0 \%)$ & $4(4.0 \%)$ & $100(100 \%)$ \\
\hline
\end{tabular}

TABLE 5: Chi Square $\left(X^{2}\right)$ Test (association between age and HBsAg infection among Undergraduate students in Gombe State University)

\begin{tabular}{lccc}
\hline Gender & Observed frequency $(\mathrm{O})$ & Expected frequency $(\mathrm{E})$ & $(\mathrm{O}-\mathrm{E})^{2}$ \\
& & & $\mathrm{E}$ \\
\hline Male & 12 & 8.46 & 1.48 \\
Female & 2 & 5.54 & 2.26 \\
Total & 14 & 13.00 & 4.74 \\
\hline
\end{tabular}




\section{Discussion}

Hepatitis B surface antigen (HBs Ag) seropositivity of $14 \%$ recorded among healthy asymptomatic student volunteers in Gombe State University implies a high incidence of hepatitis B virus infection in the study area.

In Nigeria, the prevalence ranges from 6-11\% among blood donors (Lewkonia and Rowland, 1969). The high incidence rate of $14 \%$ recorded in this study is reasonably higher than that obtained from a similar study conducted by Tribedi (1994) in zaria, Northern Nigeria. His result revealed that $8.9 \%$ of about 1860 blood donors tested positive.

Studies have also shown that the likelihood of chronicity after acute hepatitis virus infection varies and is a function of age in both immune competent and immune compromised persons (Dienstag and Isselbaher, 1998). Another study conducted by Idris in 2010 among undergraduates in ABU Zaria revealed that high rate of HBs Ag of $13 \%$ was found among the age group 19-29 years. This result concurs with the 14\% (16-25 years) prevalence rate observed in this study, similarly, higher prevalence of HBs Ag was observed in the younger age group compared to the older age groups.

Awosere et al (1999) in Ibadan also observed that the infection is most prevalent among the young age groups. This could be associated with sexual activity and intravenous drug use reported to be highest among Nigerians in their second decade or mid-twenties of life.

However, from Chi square $\left(\mathrm{X}^{2}\right)$ analysis carried out there is no significant association between age group and HBs Ag infection ( $\mathrm{P}=0.005)$; that means age has no influence on the infection. However there was a significant association between the $\mathrm{HBs} \mathrm{Ag}$ and gender $(\mathrm{P}=0.05)$; that is gender has an influence on the infection with males more predisposed to the infection than females.

\section{Conclusion And Recommendation}

This current study revealed high incidence rate of HBs $\mathrm{Ag}$ which implies that the infection is reasonably high amongst students. Students between the ages 16-25 years were the most affected (18.2\%) and also the incidence was more among male students (20\%). This emphasized the need for preventive and control measures as follows:

i. Programs (health education) aimed at enlightening the public on the dangers of hepatitis B virus and factors that could predispose them to the infection should be organized periodically

ii. Students should be properly screened before donation or acceptance of blood

iii. Awareness campaigns that are organized should be linked with that of HIV and AIDS since both Hepatitis

B virus and HIV have similar modes of transmission

iv. With the availability of effective treatment (lamivudine and interferone alpha) and vaccines (Recombivax and evergerix B), Government and other relevant authorities should supplement cost and make it easily accessible to the general public

\section{Acknowledgments}

We wish to acknowledge the management, staff and students of Gombe State University for actively participating in this study. Not forgetting the Vice Chancellor Prof. Abdullahi Mahadi, Prof. A.G Ezra HOD Department of Biological Sciences and Prof. M. D Mukhtar Deaprtment of Microbiology, Bayero University Kano.

\section{References}

[1]. S. Ahmad (2011) Prevalence of Anti-HBs antibody among children in Ahvaz, Iran, 5 years after vaccination. Jundishapur Journal of Microbiology

[2]. K. E. Awosere, O. G. Arinola and N. L Uchos (1999) Hepatitis B virus sero-prevalence among pregnant women in UCH Ibadan. Journal of Medical Laboratory Science. 8:77-82

[3]. E. A Ayoola and A. B. Adelaja (1998) Sub-determinant and Incidence of Hepatitis B antigen. Nigerian Medical Practitioner. 11: $133-136$

[4]. M. M Baba, I. S. Onwuka and S. S Baba (1998) Hepatitis B virus infection among pregnant women in Maiduguri, Nigeria. Central European Journal of Public Health. 7 (2): 62-66

[5]. M. Cheesbrough (2006) Microbiological Tests. In: District Laboratory Practice in Tropical Countries, part 2. (Cheesbrough M edn) The Cambrige University Press. 1-487

[6]. J. L Deinstag and K. J Isselbacher (1998) Chronic Hepatitis. Harrison's Principles of Internal Medicine, Vol. 1, 14 ${ }^{\text {th }}$ edition, McGraw-Hill, New York, pp 1696-1704

[7]. S. C Hadler, H. S Marjoriis and M. J Alice (1991) Hepatitis B. Evolving Epidemiology and Implications for Control. Sem. Liver. Dis. 11:84-92

[8]. T. D Harry, M. D Banjani and A. E Most (1994) Hepatitis B Virus Infection among Blood Donors and Pregnant Women in Maiduguri, Nigeria. East African Medicinal Journal. 7: 32-33

[9]. F. B Hollinger and T. J Liang (2001) Hepatitis B Virus in Knipe, DM. Eds Fields Virology $4^{\text {th }}$ edition. Philadelphia, Lippincott Williams \& Wilkins. 2971-3036

[10]. B. S Ibrahim (2005) "Islamic Medicine: 1000 years ahead of its times". Journal of Islamic Medical Association. 2: 2-9 
[11]. M. A Idris (2010) Prevalence of Hepatitis B surface Antigen among Undergraduates in Samaru Campus, Ahmadu Bello University, Zaria, Nigeria. Pp23-25

[12]. R. M Lewkonia and T. Rowland (1969) ABO Blood Group Distribution in Serum Hepatitis, British Medical Journal. 268-260

[13]. Lindsley, T. K; Skouiciis, A and Bassaris, H (1990). Control of Hepatitis B Virus Infection in Third World Countries. Journal of Transfies Medical Review, 4 (4): 187-190

[14]. S. U Mbamara and N. Obeichina (2010). Seroprevelance of Hepatitis B Surface Antigen among Antenatal Clinic Attendees in a Private Hospital in Onitsha, South East Nigeria. Nigerian Medical JournalNasidi, T. O Harry, S. O Vyavoz, G. M Munube, B. B Azzan and V. A Amaniev (1991) Prevalence of Hepatitis B Virus Markers in Representative Areas of Nigeria. International Journal of Epidemiology, 15: 274-276

[15]. E. W Nester, D. G Anderson, C. Jr Evans Roberts and M. T Nester (2007) Microbiology “A Human Perspective”. (5): 634-636

[16]. C. M. Rice and J. Dobuission (1996) Hepatitis C Virus Glycoprotein Folding: disulfide bond formation and association with calnexin. Journal of Virology. 90:778-780

[17]. E. B Tribedi (1994) Surface Antigens in Blood Donors in Zaria. Nigerian Medical Journal, 4 (2): 127 